\title{
PENGARUH PERDAGANGAN INTERNASIONAL, DAN KETERBUKAAN EKONOMI TERHADAP INDEKS PEMBANGUNAN MANUSIA DI NEGARA- NEGARA ASEAN
}

\author{
Muhammad Adnan Azzaki * \\ Universitas Islam Negeri Sunan Kalijaga Yogyakarta, Indonesia
}

\begin{abstract}
Economic openness through International Trade has a complex relationship with human development. Mainstream economies generally assume that human development automatically follows on from economic growth. This study uses human development index (HDI) as one of the indicators of development progress in aspects of human quality in the State. There are several reasons the human development index is used as an indicator of a country's development among the fundamental components of longevity, health, knowledge, and living standards. This research uses human development index (HDI) variables as dependent variables while International trade is proxies with Export, Import and economic openness values as independent variables. These variables are data located in ASEAN countries during 2013-2019. This research aims to provide information on the influence of international trade and economic openness to the Human Development Index (HDI) in ASEAN. The analysis technique used is the regression of panel data with fixed effect model. The results showed that simultaneously the Variables of Export, Import, and Economic Openness affect the human development index in ASEAN, and partially the independent variables of Export, Import, and Economic Openness have a significant effect on the Human Development Index.
\end{abstract}

JEL : F13, F10, F41

Keywords : HDI, export, import, economic opennes.

\begin{abstract}
ABSTRAK
Keterbukaan ekonomi melalui Perdagangan Internasional memiliki hubungan yang kompleks dengan pembangunan manusia. Ekonomi mainstream umumnya berasumsi bahwa pembangunan manusia secara otomatis mengikuti dari pertumbuhan ekonomi. Penelitian ini menggunakan Indeks pembangunan manusia sebagai indikator pembangunan pada aspek kualitas manusia dalam negara. Ada beberapa alasan indeks pembangunan manusia dijadikan sebagai Indikator dari pembangunan suatu negara diantara komponen mendasar yaitu umur panjang, kesehatan, pengetahuan, dan standar hidup. Penelitian ini menggunakan variabel Indeks Pembangunan Manusia (IPM) sebagai variabel dependen sedangkan perdagangan Internasional yang di proksikan dengan nilai Ekspor, Impor dan keterbukaan ekonomi sebagai variabel independen. Variabel tersebut merupakan data yang berada di negara-negara ASEAN selama tahun 2013-2019. Penelitian ini memiliki tujuan untuk memberikan informasi mengenai pengaruh perdagangan internasional dan keterbukaan ekonomi terhadap Indeks Pembangunan Manusia (IPM) di ASEAN. Teknik analisis menggunakan regresi data panel model efek tetap (Fixed Effect Model). Hasil penelitian menunjukkan bahwa secara bersamaan (Simultan) variabel Ekspor, Impor, dan Keterbukaan Ekonomi mempengaruhi indeks pembangunan manusia di ASEAN, dan secara satuan (Parsial) variabel Independen Ekspor, Impor, dan Keterbukaan Ekonomi berpengaruh signifikan terhadap Indeks Pembangunan Manusia.
\end{abstract}

Kata Kunci : IPM, ekspor, impor, keterbukaan ekonomi.

\section{PENDAHULUAN}

Pembangunan nasional yang dilakukan suatu pemerintahan di setiap negara memiliki tujuan untuk meningkatkan standar dan kualitas hidup masyarakat. Dalam rangka untuk mencapai tujuan tersebut, pemerintah senantiasa melakukan kebijakan dan melaksanakan program-program yang mendukung terjadinya suatu proses pembangunan (Afzal, Butt, Rehman \& Begum, 2009).

\footnotetext{
*Email : adnanazzaki96@gmail.com

Received : 30-05-2021, Accepted : 27-08-2021, Published : 29-08-2021

P-ISSN : 2087-9954, E-ISSN : 2550-0066. DOI : http://dx.doi.org/10.26418/jebik.v10i2.46953
} 
Diantara kawasan di dunia yang mengalami pertumbuhan pesat mengenai isu pembangunan adalah Asean. Asean merupakan salah satu wilayah yang terdapat di benua asia, yang terdiri dari mayoritas negara- negara berkembang, memiliki konsep Pan-Asianisme dalam bentuk kerja sama antar pemerintah dan memfasilitasi kegiatan ekonomi, politik, keamanan, militer, integrasi pendidikan, dan sosial budaya di antara anggotanya (Aydin, 2021).

Laporan Asian Development Bank pada tahun 2014 menyatakan bahwa diantara faktor fundamental dalam proses keberhasilan percepatan pembangunan di Asia tenggara dalam kurun waktu beberapa dasawarsa terakhir disebabkan oleh tingkat derajat keterbukaan suatu negara terhadap perekonomian dunia, terutama negara yang berorientasi terhadap ekspor dan impor, serta negara yang memiliki tata kelola yang baik (good governance) (Tanaka, 2020).

Dalam pembangunan ekonomi, Asean merupakan salah satu raksasa perekonomian dunia dengan kapasitas perdagangan barang yang masuk dalam kategori lima besar di dunia. ASEAN Secretariat (2016) mencatat transaksi perdagangan di ASEAN sekitar USD2,27 triliun dan hanya kalah dari Tiongkok, AS, dan Jerman. Diantara faktor yang memiliki pengaruh terhadap pembangunan pada suatu negara adalah perdagangan internasional (ekspor dan impor) serta keterbukaan ekonomi.

Sistem perekonomian terbuka didasarkan pada pemikiran Smith (Hye, 2012) yang menyatakan bahwa meskipun setiap orang didorong untuk mengejar kepentingan diri masingmasing, namun adanya persaingan bebas menjamin masyarakat secara keseluruhan akan menerima manfaat sehingga akan tercapailah kesejahteraan umum (general welfare). Perdagangan bebas yang merupakan bagian dari perekonomian terbuka akan menghasilkan kerja sama yang saling menutupi kekurangan akan kebutuhan terhadap suatu barang dalam negeri, sehingga konsumen memiliki lebih banyak pilihan terhadap barang dan jasa yang dibutuhkan. Perdagangan bebas juga memberikan keuntungan bagi investor untuk mengembangkan bisnis yang dibutuhkan oleh suatu negara (Mankiw, 2006).

Hal ini di dukung oleh hasil penelitian yang telah dilakukan oleh para ekonom, dalam beberapa dekade terakhir mengenai perdagangan internasional (ekspor dan impor) telah menghasilkan bukti empiris yang memiliki manfaat besar bagi negara yang menerapkan sistem perekonomian terbuka (Davies \& Quinlivan, 2006). Melalui perdagangan internasional (ekspor dan impor) serta keterbukaan ekonomi, setiap perekonomian suatu negara dapat menikmati keuntungan seperti ekspansi pasar, transfer teknologi, dan kesempatan kerja (Jawaid \& Waheed, 2017).

Beberapa penelitian telah menjelaskan manfaat dari perdagangan internasional seperti Dollar \& Kraay (2004) menyatakan, bahwa pada tahun 1980-an, kemiskinan yang absolute telah melemah dengan rencana perdagangan terbuka di negara-negara berkembang. Adanya keterbukaan perdagangan mempengaruhi pada pendapatan yang lebih besar dan dianggap sebagai sumber pengeluaran negara (fiskal) dalam rangka memberikan perlindungan sosial kepada masyarakat, mengatasi pengangguran, menyelamatkan perekonomian dari efek negatif dalam siklus bisnis, memfasilitasi kebutuhan kesehatan dan pencemaran lingkungan.

Namun permasalahan yang terjadi adalah perdagangan internasional memiliki hubungan yang kompleks dengan pembangunan manusia. Ekonomi mainstream umumnya berasumsi bahwa pembangunan manusia secara otomatis mengikuti tren dari pertumbuhan ekonomi. Karena perdagangan internasional hanya berperan penting terhadap pertumbuhan ekonomi saja (Sharma 
\& Gani, 2004). Menurut United Nation Development Programe (UNDP) paradigma mengenai indikator kesuksesan suatu pembangunan juga harus dikaitkan dengan kualitas manusianya. Dalam hal ini indeks pembangunan manusia (IPM) dijadikan sebagai indikator kemajuan ekonomi dan masyarakat suatu negara (Sharma \& Gani, 2004).

Menurut Barrington-Leigh \& Escande (2017) indikator kesuksesan pada proses pembangunan melalui pelaksanaan fungsi dan tugas pemerintah di setiap negara adalah terjadinya peningkatan kesejahteraan masyarakat sejalan dengan terjadinya penurunan angka penduduk miskin di suatu negara. Hal ini diperkuat oleh para ahli perencanaan pembangunan dan ekonomi, yang menyatakan bahwa dalam pelaksanaan pembangunan yang menjadi prioritas utama adalah membangun faktor manusia (Halid \& Yapanto, 2021). Karena indikator pembangunan suatu negara yang diukur secara kuantitatif ekonomis seperti pertumbuhan ekonomi dirasakan belum mampu menjamin tingkat kesejahteraan masyarakat (Wibowo, 2016).

Secara teoritis dan beberapa studi empiris telah membahas mengenai hubungan antara perdagangan internasional dan pembangunan manusia. Di mulai dari kerangka konseptual antara perdagangan dan pembangunan manusia disampaikan dalam Asia Pacific Human Development Report (UNDP, 2006). Menurut kerangka kerja ini, indikator tingkat pertumbuhan dan struktur perekonomian telah diubah menjadi perdagangan melalui modal dan tenaga kerja dari suatu negara. Tenaga kerja terampil telah dihargai lebih dari tenaga kerja yang tidak terampil oleh perdagangan. Hal ini menuntut adanya kompetensi dan keterampilan yang tinggi serta wewenang dari pembuat kebijakan. Sehingga pada akhirnya, pembangunan manusia juga dapat mempengaruhi secara langsung struktur perekonomian, laju pertumbuhan, dan perdagangan. sebagaimana juga perdagangan mempengaruhi indeks pembangunan manusia (Jawaid \& Waheed, 2017).

Selain itu keterbukaan ekonomi diyakini dapat mendorong pertumbuhan ekonomi suatu negara (Kong, Peng, Ni, Jiang \& Wang, 2021). Nowbutsing (2014) mengatakan bahwa keterbukaan merupakan sarana untuk mempromosikan pertumbuhan melalui penelitian dan pengembangan serta akses pasar yang lebih luas. Beberapa anggapan mengenai keterbukaan ekonomi dan indeks pembangunan manusia telah banyak memberikan gambaran mengenai keuntungan yang nantinya dapat diperoleh, keuntungan-keuntungan tersebut nantinya diharapkan mampu menggerakkan peningkatan kualitas sumberdaya manusia dalam negeri. Pendapat ini didukung oleh penelitian Suri, Boozer, Ranis \& Stewart (2011) menyimpulkan bahwa perbaikan dari pembangunan manusia membantu mencapai pertumbuhan ekonomi yang lebih tinggi dan sebagai akibat dari pertumbuhan ekonomi ini juga akan mendorong pembangunan manusia. Pendapat ini membuktikan adanya hubungan antara pertumbuhan ekonomi dan pambangunan manusia, sehingga pertumbuhan tanpa memperbaiki pembangunan manusia tidak dapat menciptakan keseimbangan yang berkelanjutan (Lumbantoruan \& Hidayat, 2013). 


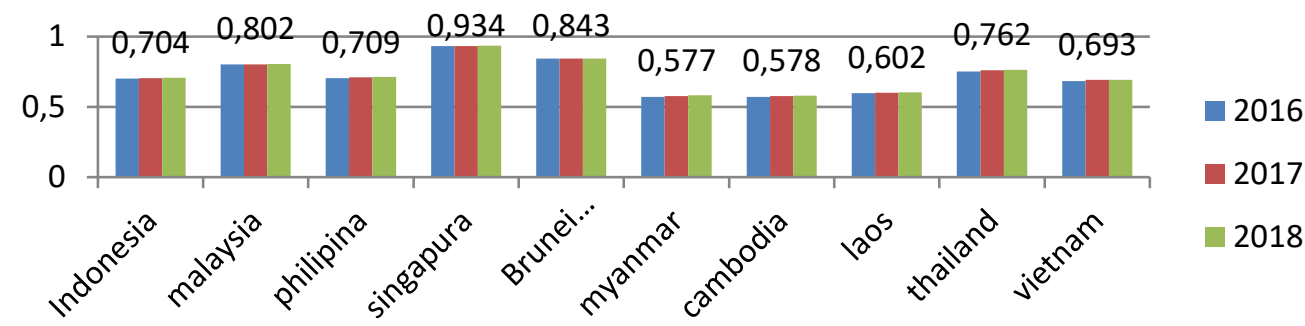

Sumber : UNDP, 2019

\section{Gambar 1. Indeks Pembangunan Manusia (IPM) di Asean}

Indeks pembangunan manusia terbentuk dari empat komponen mendasar yaitu umur panjang, kesehatan, pengetahuan, dan standar hidup, selain itu IPM juga hasil dari rata-rata geometrik normalisasi indeks untuk masing-masing dimensi. Dimensi kesehatan yang dinilai oleh harapan hidup pada tingkat kelahiran. Dimensi pendidikan diukur dengan lama sekolah sampai dewasa diatas 25 tahun. Standar dimensi hidup diukur dengan produk domestik bruto (PDB) per kapita (Arisman, 2018).

Berdasarkan gambar 1, di peroleh data IPM yang terdapat di sepuluh negara Asean dalam periode tahun 2016-2018. Singapura, Brunei Darussalam, dan Malaysia termasuk dalam kategori indeks pembangunan manusia yang sangat tinggi. Indonesia dan Thailand termasuk dalam indeks pembangunan manusia yang tinggi, Vietnam, Filipina, Kamboja, Laos, dan Myanmar termasuk dalam indeks pembangunan manusia menengah. Data diatas menunjukkan bahwa terdapat prioritas perbedaan kebijakan pemerintah di antar negara.

Oleh karena itu menarik untuk diketahui apakah proses pembangunan melalui perdagangan internasional (ekspor dan impor) serta keterbukaan ekonomi yang ada di Asean berdampak terhadap kesejahteraan dan kualitas pembangunan masyarakat yang di representasikan melalui indeks pembangunan manusia (IPM). Sehingga penelitian ini memiliki tujuan untuk memberikan informasi dan sebagai bahan kajian mengenai pengaruh perdagangan internasional (ekspor dan impor) dan keterbukaan ekonomi terhadap indeks pembangunan manusia (IPM) di negara - negara Asean pada tahun 2013-2019.

\section{KAJIAN LITERATUR}

\subsection{Indeks Pembangunan Manusia (IPM)}

Indeks Pembangunan Manusia (IPM) merupakan konsep yang dikembangkan oleh Amarta Sen tahun 1998, yang merupakan peraih nobel ekonomi asal India, dan ekonom dari Pakistan yang bernama Mahbub (Bagolin, 2014). IPM merupakan indikator yang dijadikan alat ukur melalui standar pencapaian suatu negara. Terdapat tiga standar dasar yang menjadi ukuran dari IPM terhadap suatu pembangunan manusia. Pertama, panjang kehidupan (length of life) merupakan representasi angka harapan hidup. Kedua, pendidikan (education) merupakan kombinasi antara angka melek huruf dan rata-rata lama sekolah. Ketiga, standar hidup layak yang di representasikan oleh pengeluaran rata-rata penduduk yang telah ditentukan (PPP Rupiah). Rumus menghitung IPM menurut (Lamba, Novan, Lamba \& Patma, 2020) adalah sebagai berikut :

$$
I P M=\frac{1}{3}\left(\operatorname{Index} X_{1}+\operatorname{Index} X_{2}+\operatorname{Index} X_{3}\right)
$$


Dimana:

Index $X_{1} \quad=$ Harapan hidup

Index $X_{2} \quad=$ Tingkat pendidikan

Index $X_{3}=$ Standar hidup layak (decent standard of living).

Langkah yang dilakukan sebelum melakukan perhitungan terhadap IPM adalah menghitung setiap komponen dari masing- masing indeks dengan rumus sebagai berikut:

$\mathrm{X}_{1}=\mathrm{X}_{1}-\mathrm{X}_{\min } / \mathrm{X}_{\max }-\mathrm{X}_{\min }$

Dimana:

$\mathrm{X}_{(1)} \quad=$ Komponen IPM untuk i

$X_{(\min )}=$ Nilai minimum dari komponen IPM

$X_{(\max )}=$ Nilai maksimum daari komponen IPM

\subsection{Data Panel}

Data panel adalah himpunan data cross section dan time series. Artinya data panel merupakan gabungan data yang bersifat multidimensi. Multidimensi dapat diartikan sebagai data yang memiliki unsur observasi seperti fenomena yang diukur dan periode kumpulan data lebih dari satu waktu untuk satu individu yang sama (Bollen \& Brand, 2010). Menurut Hsiao (2003) data panel memiliki kelebihan sebagai berikut :

- Dapat memberikan peneliti jumlah pengamatan besar, meningkatkan derajat kebebasan, data memiliki variabilitas yang besar dan mengurangi multikolinearitas antara variabel penjelas, dimana dapat menghasilkan estimasi ekonometrika yang efisien.

- Data panel memberikan informasi lebih banyak yang tidak dapat diberikan hanya oleh data cross section dan time series saja.

- Data panel akan memberikan penyelesaian yang lebih baik dalam inferensi perubahan dinamis dibandingkan dengan data cross section..

Berikut adalah persamaan model data panel :

$Y_{i}=\beta_{0}+\beta_{1} X_{i}+\varepsilon_{i} ; i=1,2,3, \ldots, N Y_{i}$

Dalam persamaan 1, diketahui bahwa N adalah banyaknya data cross section. Sedangkan persamaan model dengan time series dapat ditulis sebagai berikut:

$$
Y_{t}=\beta_{0}+\beta_{1} X_{i}+\varepsilon_{i} ; i=1,2,3, \ldots, N Y_{i}
$$

Dalam persamaan 2, diketahui bahwa $\mathrm{T}$ adalah banyaknya data time series. Sehingga persamaan data panel merupakan pengkombinasian dari persamaan cross section dan time series dapat ditulis sebagai berikut:

$$
Y_{i t}=\beta_{0}+\beta_{1} Y_{i t}+\varepsilon_{i t} ; i=1,2,3, \ldots, N ; t=1,2,3, \ldots, T .
$$

Dalam persamaan 3, diketahui bahwa $\mathrm{Y}$ adalah variabel dependen, $\mathrm{X}$ adalah variabel independen, $\mathrm{N}$ adalah banyaknya observasi, $\mathrm{T}$ adalah banyaknya waktu, dan $\mathrm{N}$ x $\mathrm{T}$ adalah banyaknya data panel. 
Terdapat tiga jenis model yang bisa digunakan untuk regresi data panel, antara lain : yaitu OLS (pooled), efek tetap (fixed effects) atau efek random (random effect) (Gujarati \& Mangunsong, 2012).

\section{Pooled Least Square (PLS)}

Model ini dikenal juga dengan common effect model, yang merupakan strategi model data panel sederhana, hal ini dikarenakan data time series dan cross section hanya di kombinasikan. Model ini bisa menggunakan pendekatan $O L S$ dalam menghitung estimasi data panel. Pendekatan ini tidak berfokus pada dimensi individu maupun waktu. Sehingga dapat dikatakan bahwa regresi panel yang dihasilkan akan berlaku untuk setiap individu (Widarjono, 2017). Berikut adalah model persamaannya :

$$
Y_{i t}=\beta_{0}+\beta_{1} X_{1 i t}+\beta_{2} X_{2 i t} \text { untuk i }=1,2, \ldots \mathrm{T}
$$

Maksud dari $\mathrm{N}$ adalah individu dan $\mathrm{T}$ adalah deret waktu. Metode PLS memberi asumsi bahwa nilai (a) dan koefisien variabel bebasnya ( $\beta$ ) konstan untuk setiap individu. Model PLS tidak menghiraukan karakter individu sehingga model ini tidak dijadikan pilihan utama (Sholiha, 2015).

\section{Fixed Effect Model}

Model ini menjelaskan bahwa perbedaan yang terdapat antar individu bisa diakomodasi dari perbedaan intersepnya. Dalam melakukan estimasi data panel model fixed effects menggunakan teknik variabel dummy, namun demikian slopnya sama. Model perhitungan ini sering juga disebut dengan teknik LSDV (Bollen \& Brand, 2010). LSDV dengan dummy variabel banyak digunakan karena relatif mudah menjabarkan hasilnya. Model ini memiliki asumsi bahwa koefisien regresi tetap antar cross section dan antar waktu (Widarjono, 2017). Berikut adalah bentuk persamaan model FEM :

$$
Y_{i t}=\beta_{0 i}+\beta_{1} X_{1 i t}+\beta_{2} X_{2 i t} ;=1,2,3,4,5 \text { (objek penelitian) } \mathrm{t}=1,2,3,4 \text { (tahun) }
$$

Dengan $\beta 0$ i merupakan intersep dan $\beta 1, \beta 2$ merupakan slope, pada persamaan tersebut, penambahan subscript i pada intersep yang menunjukkan bahwa terdapat perbedaan intersep setiap objek penelitian, disebabkan oleh perbedaan kinerja masing-masing objek penelitian.

Dalam analisisnya jika intersep berbeda dengan individu dan waktu, maka dapat menggunakan differential dummy variabel. Dengan persamaan sebagai berikut :

$$
Y_{i t}=\alpha_{1}+\alpha_{1} D_{2 i}+\alpha_{3} D_{3 i}+\alpha_{n} D_{n i}+\beta_{1} X_{1 i t}+\beta_{2} X_{2 i t}
$$

Maksud dari n adalah individu untuk dummy variabel, i merupakan individu sampel, dan t merupakan waktu. Model ini menggunakan dummy variabel.

\section{Random Effect Model}

REM atau yang dikenal juga dengan model efek random adalah variasi dari estimasi GLS. Model ini melakukan estimasi data panel, yaitu variabel gangguan saling berhubungan antar waktu dan antar individu.

Model ini di ukur menggunakan GLS jika struktur kovarians diketahui dan menggunakan EGLS jika struktur kovarians tidak diketahui. EGLS pertama kali harus menghitung $\theta$ 
menggunakan $\sigma \mathrm{u}^{2}$ dan $\sigma \mathrm{v}^{2} . \sigma \mathrm{u}^{2}$ didapatkan dari regresi rata-rata kelompok dan $\sigma \mathrm{v}^{2}$ didapatkan dari SSE estimasi within.

$$
\sigma_{y}^{2}=\frac{S S E \text { (within) }}{n T-n-k}=\frac{\grave{\mathrm{è}} \text { (within) }}{n T-n-k}=\frac{€ £(v 2-v 1) 2}{n T-n-k}
$$

Transformasi berubah menjadi

$$
\begin{aligned}
& \dot{y}_{u}=y_{u}-\theta \dot{y}_{1} \\
& \dot{x}_{u}=x_{u}-\theta x_{1 \text { for all } x_{k}} \\
& \dot{\alpha}=1-\theta
\end{aligned}
$$

Persamaan regresi yang baru hasil transformasi inilah yang merupakan model "between"

$$
Y_{i t}=\beta_{0 i}+\beta_{1} X_{1 i t}+\beta_{2} X_{2 i t}
$$

REM memiliki perbedaan dengan model FEM, pada model REM persamaan $\beta 0$ i dianggap tidak konstan, tetapi sebagai peubah random dengan $t$ dari nilai rata-rata $\beta_{1}$ (tanpa i). Efek tetap (Fixed Effect) dilakukan uji dengan uji $\mathrm{F}$ sedangkan efek random (Random Effect) dilakukan dengan uji LM. Persamaan estimasi efek tetap dan efek random akan diuji menggunakan uji Hausman.

Selanjutnya dalam menentukan model yang tepat yang akan digunakan dalam menghitung ukuran regresi data panel, terdapat tiga jenis uji yang akan dilakukan diantaranya: Uji Chow, Uji Hausman dan Lagrange Multiplier :

\section{Uji Chow}

Liabilitas dapat terjadi dimana ketika koefisien kemiringan mempunyai nilai yang sama untuk antar waktu dan kelompok (Herawati \& Fauzia, 2018). Hipotesis uji chow ini adalah :

$$
\text { HO : } \beta \text { ik }=\beta k
$$

Pengujian statistik menggunakan :

$$
f(n-1)(k+1), n(T-k-1)=\frac{(\mathrm{e}, \mathrm{è}-€ \mathrm{è,} \mathrm{è}) /(n-1)(k+1)}{£ \text { è, }, / n(T-k-1)}
$$

Jika Ho ditolak, data panel tidak poolable (tidak dapat disatukan), dapat diartikan setiap individu mempunyai koefisien regresi yang berbeda untuk semua regresor.

Selanjutnya Uji Chow menentukan model terbaik antara Common Effect Model (CEM) dan Fixed Effect Model (FEM) menggunakan hipotesis berikut.

$H_{0} \quad: \alpha_{1}=\alpha_{2}=\alpha_{3}=\cdots=\alpha_{N}=\alpha($ Common Effect Model $)$

$H_{1} \quad$ : minimal ada satu $\alpha_{\mathrm{i}}$ yang berbeda. (Fixed Effect Model) $\mathrm{i}=1,2,3, \ldots \mathrm{N}$

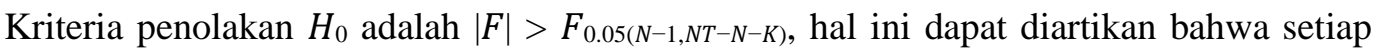
intersep untuk semua unit cross section tidak akan sama sehingga model persamaan regresi yang digunakan adalah Fixed Effect Model, namun sebaliknya jika $\mathrm{H}_{0}$ diterima maka persamaan regresi yang digunakan adalah Common Effect Model (CEM). Dengan hipotesis :

$\mathrm{H}_{0}$ : Model mengikuti Common Effect

Ha: Model mengikuti Fixed Effect. 
Adapun ketentuannya adalah, jika probabilitas dari Cross-section Chi-square $>0,05$ maka $\mathrm{H}_{0}$ diterima, namun jika probabilitas Cross-section Chi-square< 0,05 maka $\mathrm{H}_{0}$ ditolak.

\section{Uji Hausman}

Dalam menentukan model yang terbaik, maka uji ini melakukan perbandingan antara model efek tetap dan model efek random. Hipotesis nol menjelaskan bahwa efek individu tidak mempunyai korelasi dengan regresi pada model. Jika hipotesis nol tidak dilanggar, LSDV dan GLS konsisten.

$$
\begin{aligned}
& L M=\left(b_{l s d v}-b_{l s d v}\right) W^{-1}\left(b_{l s d v}-b_{\text {random }}\right) \sim X^{2}(k) \\
& \text { Where } W=\operatorname{Var}\left(b_{l s d v}-b_{\text {random }}\right)=\operatorname{Var}\left(b_{l s d v}\right)-\operatorname{Var}\left(b_{\text {random }}\right)
\end{aligned}
$$

Apabila hipotesis nol ditolak, maka terdapat korelasi efek individu dengan regresor, maka model efek random memiliki masalah sehingga model terbaik yang digunakan adalah model efek tetap (Fixed Effect). Hipotesis yang digunakan adalah sebagai berikut:

$\mathrm{H}_{0}$ : Model mengikuti Random Effect

Ha: Model mengikuti Fixed Effect

Dengan ketentuan, jika probabilitas Cross-section Random> 0,05 maka $\mathrm{H}_{0}$ diterima, tetapi jika probabilitas Cross-section Random< 0,05 maka $\mathrm{H}_{0}$ ditolak dan $\mathrm{H}_{\mathrm{a}}$ diterima.

\section{Uji LM Breusch-Pagan}

Breusch dan Pagan's dalam (Acaravci \& Akalin, 2017) Lagrange Multiplier merupakan pengujian komponen varians dari individu tertentu adalah nol Ho $=\sigma_{u}^{2}$ Statistik LM mengikuti distribusi chi kuadrat dengan derajat bebas 1 .

$$
L M_{u}=\frac{n T}{2(T-I)}\left\{\frac{T 2 \overline{\mathrm{e} e} \mathrm{e}}{\text { èè }}-1\right\} 2 \sim X^{2(1)}
$$

Apabila hipotesis nol ditolak, maka dapat disimpulkan telah terjadi efek random yang signifikan pada data panel dan model efek random dapat mengatasi heterogenitas lebih baik dari PLS Pooled. Kriteria penolakan $H_{0}$ adalah jika $L M>\mathrm{X}_{\mathrm{k} ; 0.05}(\mathrm{~K}=$ jumlah variabel) artinya model terbaik yang digunakan adalah Random Effect Model, tetapi jika sebaliknya, maka model terbaik yang digunakan adalah Common Effect Model.

\subsection{Perdagangan Internasional}

Argumen standar untuk hubungan positif antara perdagangan dan pembangunan manusia adalah bahwa lebih banyak perdagangan melahirkan standar hidup yang lebih besar yang, pada gilirannya, melahirkan lebih banyak pendidikan, perawatan kesehatan dan layanan sosial yang lebih baik. perdagangan memiliki pengaruh terhadap pendapatan langsung, dan pengaruh pada pendapatan tidak langsung. Argumen yang lebih luas atau "globalis" adalah bahwa perdagangan berdampak pada langkah-langkah pembangunan manusia non-pendapatan baik secara tidak langsung melalui pendapatan maupun langsung melalui pembuahan lintas budaya dan peningkatan berbagai barang yang tersedia (Davies \& Quinlivan, 2006).

Aktivitas perdagangan internasional akan menghasilkan bea cukai, pajak dan pundi-pundi lain yang berpengaruh pada peningkatan penerimaan dan belanja negara. Kemudian belanja pemerintah yang naik tersebut juga akan membesarkan aliran dana yang dapat digunakan untuk 
mendanai kegiatan-kegiatan atau pengadaan fasilitas-fasilitas yang dapat menunjang peningkatan kualitas masyarakat (Diputra, 2017).

Penelitian terkait pengaruh perdagangan internasional terhadap indeks pembangunan manusia telah banyak dilakukan oleh penelitian sebelumnya dengan berbagai metode yang digunakan. Razmi \& Yavari (2012) melakukan penelitian mengenai efek keterbukaan perdagangan terhadap pembangunan manusia menggunakan data panel 11 negara kaya minyak dari 1998 hingga 2009 dan menemukan efek positif perdagangan yang signifikan keterbukaan terhadap pembangunan manusia. Hamid \& Amin (2013) menyelidiki hubungan antara perdagangan dan pembangunan manusia dengan menggunakan data panel 38 anggota di organisasi negara Islam (OKI). Model ARDL menunjukkan hubungan positif yang signifikan antara perdagangan dan IPM.

Eusufzai (1996) menemukan hubungan positif antara keterbukaan perdagangan dan pengembangan termasuk IPM dan langkah-langkah pembangunan manusia lainnya yang dipertimbangkan oleh UNDP. Hal Ini memberi indikasi bahwa ekonomi yang lebih terbuka memiliki tingkat IPM yang lebih tinggi.

Variabel selanjutnya adalah Impor, impor yang tinggi jika tidak di seimbangkan dengan ekspor yang tinggi akan menyebabkan defisit neraca perdagangan pada suatu negara. Defisit perdagangan akan meningkatkan beban biaya pada nilai impor maupun transaksi perdagangan (current account balance). Hubungan antara impor dan indeks pembangunan manusia terjadi melalui pertumbuhan ekonomi dapat di klasifikasikan menjadi dua hipotesis yaitu: import-led growth, dimana pada hipotesis ini menjelaskan bahwa impor menyebabkan pertumbuhan dan growth-led import, dimana hipotesis ini menjelaskan bahwa pertumbuhan menyebabkan impor (Hye, 2012). Penelitian yang telah dilakukan oleh Hye \& Lau (2015) di Tunisia, Ashraf, Weil \& Wilde (2011) di Pakistan, serta Hye (2012) di China menemukan bahwa ada hubungan negatif dua arah pada variabel impor terhadap pertumbuhan ekonomi, sehingga kedua hipotesis, baik importled growth dan growth-led import secara bersama-sama dapat di buktikan.

\subsection{Keterbukaan Ekonomi}

Keterbukaan terhadap perekonomian global merupakan bagian dari ide pokok dalam konsesus Washington, hal ini didasarkan bahwa keterbukaan ekonomi tercipta melalui liberalisasi perdagangan dan investasi asing langsung (Golub, 2009). Kebijakan mengenai keterbukaan ekonomi di suatu negara merupakan bagian dari upaya untuk meningkatkan pertumbuhan ekonomi. Semakin terbuka suatu perekonomian, maka semakin tinggi integrasi pada pasar barang dan pasar modal dunia. Akumulasi dari kebijakan keterbukaan ekonomi tersebut memiliki kontribusi terhadap potensi keuntungan dalam pertumbuhan ekonomi dan kesejahteraan masyarakat (Calderón, 2004). Keterbukaan ekonomi menjadikan suatu negara memiliki aksesakses yang lebih luas dalam upaya meningkatkan pembangunan dan meminimalisir hambatan yang terjadi dalam proses peningkatan pembangunan tersebut.

Teori ini diperkuat oleh penelitian Pernia \& Quising (2005) menyelidiki keterbukaan ekonomi dan pembangunan kawasan di negara Filipina. Dengan menggunakan data panel di 14 kawasan yang ada di Filipina selama lima tahun. Hasil dari penelitian menemukan bahwa keterbukaan ekonomi melalui perdagangan dapat mempengaruhi pertumbuhan ekonomi serta pembangunan di 14 kawasan yang ada di filipina. 
Berdasarkan tinjauan literatur, teori dan argumentasi di atas perbedaan penelitian ini dengan sebelumnya adalah terletak pada pengembangan mengenai isu perdagangan internasional yang biasanya hanya dikaitkan dengan pertumbuhan ekonomi, dan sekaligus dijadikan indikator. Dalam perspektif yang lebih luas indikator kesuksesan dari perdagangan internasional tersebut harus dilihat dalam pengaruhnya terhadap indeks pembangunan manusia (IPM) yang merupakan bagian substansi dari segala bentuk kebijakan yang dilakukan oleh suatu negara (UNDP, 2006), atas dasar itu maka hipotesis yang di tawarkan dalam penelitian ini adalah sebagai berikut :

$\mathrm{H}_{1}$ : Ekspor memiliki hubungan positif terhadap Indeks Pembangunan Manusia (IPM)

$\mathrm{H}_{2}$ : Impor memiliki hubungan positif terhadap Indeks Pembangunan Manusia (IPM)

$\mathrm{H}_{3}$ : Keterbukaan ekonomi memiliki hubungan positif terhadap Indeks Pembangunan Manusia (IPM).

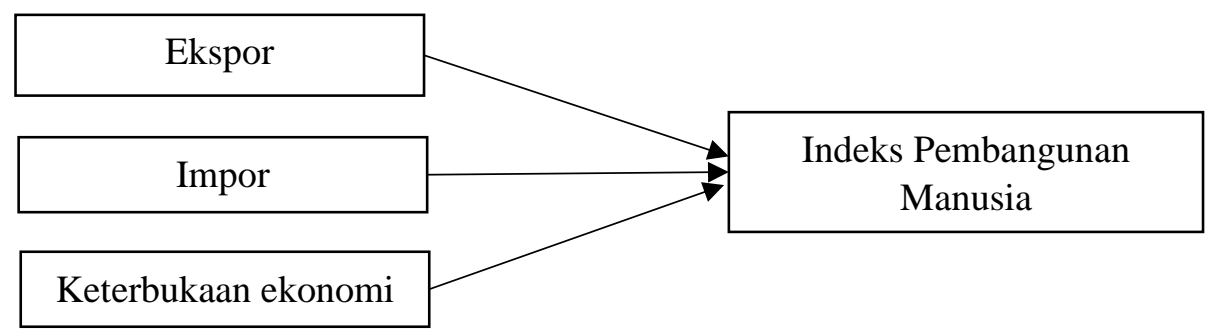

Gambar 2. Kerangka Penelitian

\section{METODE PENELITIAN}

\subsection{Jenis dan Sumber data}

Jenis dan sumber data dalam penelitian ini menggunakan data kuantitatif bersifat sekunder yang di keluarkan oleh World Bank. Data dalam penelitian ini merupakan data tahunan. Selama periode tahun 2013 sampai 2019. Metode pengambilan sampel dalam penelitian ini adalah purposive sampling yaitu suatu metode pengambilan sampel yang menggunakan kriteria tertentu. Penggunaan kriteria dalam penelitian ini adalah negara-negara di Asean yang telah mempublikasi data-data yang di butuhkan dalam penelitian ini yaitu data ekspor, impor dan perhitungan rasio keterbukaan ekonomi. Negara-negara tersebut adalah Singapura, Indonesia, Brunei Darussalam, Filipina, Malaysia, Kamboja, Thailand, Vietnam, dan Myanmar.

\subsection{Definisi Operasional Variabel}

Penelitian ini menjadikan Indeks Pembangunan Manusia (IPM) sebagai variabel dependen dan perdagangan internasional yang di proksikan dengan nilai ekspor, impor dan keterbukaan ekonomi sebagai variabel independen. Variabel-variabel tersebut merupakan data yang berada di negara-negara Asean. Definisi operasional variabel dalam penelitian ini sebagai berikut:

\section{Variabel Dependen}

Indeks pembangunan manusia (IPM) adalah tolak ukur penting dalam melihat keberhasilan kualitas pembangunan suatu negara, terutama pembangunan manusia. IPM menjadi indikator dalam menilai bagaimana penduduk dapat memiliki akses dari hasil pembangunan melalui kesehatan, pendidikan, dan pendapatan. 
2. Variabel Independen

a. Ekspor merupakan proses transaksi penjualan barang atau jasa dari suatu negara ke negara lain secara legal. Dalam penelitian ini, nilai ekspor (X1) menggunakan data dari tahun 2013 sampai dengan tahun 2019 di negara-negara Asean, data ini menggunakan nilai dalam satuan US\$.

b. Impor merupakan proses pembelian barang atau jasa dari suatu negara ke negara lain secara. Dalam penelitian ini, nilai impor (X2) menggunakan data dari tahun 2013 sampai dengan tahun 2019 di negara-negara Asean, data ini menggunakan nilai dalam satuan US\$.

c. Keterbukaan ekonomi diukur melalui rasio antara ekspor dan impor terhadap produk domestik bruto. Data keterbukaan perdagangan yang digunakan merupakan data keterbukaan perdagangan dari tahun 2013 sampai 2019 di negara Asean.

\subsection{Metode Analisis}

Dalam penelitian ini, untuk mengetahui pengaruh perdagangan internasional dan keterbukaan ekonomi terhadap Indeks Pembangunan Manusia (IPM) pada periode 2013-2019 menggunakan model regresi data panel. Penelitian menggunakan model regresi data panel ini dibantu dengan software ekonometrika eviews 9, yang kemudian dilanjutkan dengan melakukan serangkaian pengujian yang meliputi uji pemilihan model menggunakan Uji Chow dan Uji Hausman. Pengujian yang kedua adalah uji F dan uji T.

Variabel terikat pada penelitian ini adalah IPM, dan variabel bebas dari penelitian ini adalah nilai ekspor $\left(\mathrm{X}_{1}\right)$, nilai impor $\left(\mathrm{X}_{2}\right)$, dan keterbukaan ekonomi $\left(\mathrm{X}_{3}\right)$. Secara umum didapat model persamaan $\beta$ adalah sebagai berikut:

$$
Y=\beta_{0}+\beta_{1} X_{1 i t}+\beta_{2} X_{2 i t}+\beta_{3} X_{3 i t}+e
$$

Keterangan :

$\begin{array}{ll}Y & =\text { Indeks Pembangunan Manusia } \\ t & =\text { Waktu } \\ \beta_{0} & =\text { Konstanta } \\ \beta_{1}-\beta_{3} & =\text { Koefisien Regresi dari Setiap Variabel Independen } \\ X_{1} & =\text { Ekspor } \\ X_{2} & =\text { Impor } \\ X_{3} & =\text { Keterbukaan Ekonomi } \\ e & =\text { Standar kesalahan (error) }\end{array}$

\subsection{Pemilihan Model Regresi Panel}

Adapun prosedur pengujian dalam memilih model yang terbaik dalam regresi panel adalah sebagai berikut:

A. Uji Chow-test atau Likelihood Ratio-test merupakan pengujian yang dilakukan dalam memilih model terbaik antara Common Effect atau Fixed Effect. pengujian ini menggunakan Hipotesis sebagai berikut: $\mathrm{H}_{0}$ : Model mengikuti Common Effect $\mathrm{H}_{\mathrm{a}}$ : Model mengikuti Fixed Effect 70 Adapun ketentuannya adalah, jika probabilitasnya dari Cross- 
section Chi-square > 0,05 maka $\mathrm{H}_{0}$ diterima, namun jika probabilitasya Cross-section Chisquare $<0,05$ maka $\mathrm{H}_{0}$ ditolak.

B. Uji Hausman test merupakan pengujian yang dilakukan untuk menentukan model terbaik antara Fixed Effect atau Random Effect. Hipotesis yang digunakan adalah $\mathrm{H}_{0}$ : Model mengikuti Random Effect $\mathrm{H}_{\mathrm{a}}$ : Model mengikuti Fixed Effect dengan ketentuan: jika

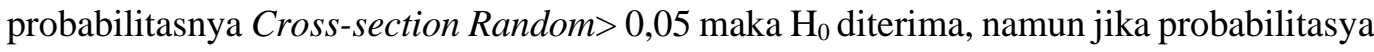
Cross-section Random< 0,05 maka $\mathrm{H}_{0}$ ditolak.

C. Uji LM Lagrange Multiplier (LM) merupakan uji untuk mengetahui model yang paling tepat digunakan antara Random Effect atau model Common Effect. Uji signifikasi Random Effect ini dikembangkan oleh Breusch Pagan. Metode Breusch Pagan untuk uji signifikasi Random Effect didasarkan pada nilai residual dari metode OLS. Pengujian ini dilakukan dengan hipotesis sebagai berikut:

a. H0: Common Effect Model

b. H1: Random Effect Model

Jika nilai probabilitas Breush-Pagan (BP) lebih kecil dari 0.05 maka H0 ditolak maka model yang dipilih adalah random effect. Sebaliknya, jika nilai probabilitas Breush-Pagan (BP) lebih kecil dari $0.05 \mathrm{H} 1$ diterima, jadi model yang tepat adalah common effect.

D. Uji Hipotesis analisis regresi data panel ini merupakan uji kebenaran hipotesis yang telah ditetapkan dan diinterpretasikan hasilnya. Software Eviews 9 digunakan untuk memudahkan pengolahan data dengan melihat output yang dihasilkan antara lain:

1) Koefisien Determinasi

Koefisien determinasi (R2) digunakan untuk mengukur seberapa besar kemampuan model dalam menerangkan variasi dari variabel dependen. Kecilnya nilai R2 menunjukan bahwa kemampuan variabel-variabel independen dalam menjelaskan variabel dependen sangatlah terbatas. Nilai R2 dimulai dari angka 0 sampai dengan 1 . Nilai yang mendekati satu berarti variabel-variabel independen memberikan hampir semua informasi yang dibutuhkan untuk memprediksi variabel independen. R2memiliki kelemahan yang mendasar yaitu hasilnya bias terhadap variabel independen yang dimasukan ke dalam model. Karena setiap tambahan satu variabel independen akan menyebabkan nilai R2 meningkat tidak peduli variabel tersebut berpengaruh signifikan atau tidak terhadap variabel independen. Untuk mengatasi hal tersebut, maka digunakanlah nilai Adjusted R2 (Leach, Henson, Finch, Newman \& Walker, 2007).

2) Uji Statistik F

Uji statistik F digunakan untuk menguji secara simultan atau bersama-sama pengaruh dari variabel independen terhadap variabel dependen. Pengambilan keputusannya berdasarkan hipotesis berikut: H0: Variabel independen secara simultan atau bersama-sama tidak berpengaruh terhadap variabel dependen. Ha: Variabel independen secara simultan atau bersama-sama berpengaruh terhadap variabel dependen. Adapun cara pengambilan keputusan uji statistik $\mathrm{F}$ adalah sebagai berikut: Jika nilai signifikansi $<(\alpha 0,05)$ maka H0 ditolak Jika nilai signifikansi $>$ $(\alpha 0,05)$ maka $\mathrm{H} 0$ diterima. 
3) Uji t (Uji Parsial)

Uji statistik t digunakan untuk menguji koefisien regresi secara parsial atau individual pengaruh dari variabel independen terhadap variabel dependen. Pengambilan keputusannya berdasarkan hipotesis sebagai berikut: H0: Masing-masing variabel independen secara parsial atau individual tidak berpengaruh terhadap variabel dependen. Ha: Masing-masing variabel independen secara parsial atau individual berpengaruh terhadap variabel dependen. Adapun cara pengambilan keputusan uji statistik t adalah sebagai berikut:

- Jika nilai signifikansi $<(\alpha 0,05)$ maka $\mathrm{H} 0$ ditolak

- Jika nilai signifikansi $>(\alpha 0,05)$ maka H0 diterima.

\section{HASIL DAN PEMBAHASAN}

Statistik deskriptif merupakan salah satu metode untuk meringkas, mendeskripsikan dan menggambarkan data-data kedalam informasi yang lebih sederhana dan mudah dipahami. Statistik deskriptif menggunakan metode grafis untuk mengenali pola sejumlah data dan merangkum informasi yang terdapat dalam data tersebut, sehingga dalam penyajiannya mudah untuk diinformasikan.

Tabel 1. Statistik Deskriptif

\begin{tabular}{lcccc}
\hline & Ekspor & Impor & Keterbukaan ekonomi & IPM \\
\hline Mean & $1.84 \mathrm{E}+11$ & $1.70 \mathrm{E}+11$ & 1,287558 & 0,729159 \\
Maximum & $6.63 \mathrm{E}+11$ & $5.57 \mathrm{E}+11$ & 3,670418 & 0,938000 \\
Minimum & $5.65 \mathrm{E}+09$ & $4.30 \mathrm{E}+09$ & 0,373034 & 0,543000 \\
Std. Dev. & $1.80 \mathrm{E}+11$ & $1.53 \mathrm{E}+11$ & 0,851677 & 0,112860 \\
Observations & 63 & 63 & 63 & 63 \\
\hline
\end{tabular}

Tabel 1 menunjukan jumlah observasi sebanyak 63, terdiri dari 9 negara yang ada di Asean selama tahun 2013-2019. Ekspor mempunyai nilai paling rendah sejumlah 5,65 miliar dolar dan nilai paling tinggi sebesar 663 miliar dolar serta secara menyeluruh, variabel export memiliki nilai rata-rata 184 miliar dolar serta standar deviasi sebesar 180 miliar dolar. Impor mempunyai nilai paling rendah sebesar 4.3 miliar dolar serta nilai paling tinggi sebesar 557 miliar dolar, kemudian secara menyeluruh, variabel impor memiliki angka rata-rata 170 miliar dolar dan standar deviasi 152 miliar dolar. Keterbukaan ekonomi mempunyai angka paling rendah 0.3, angka tertinggi 3.6, dan secara menyeluruh variabel keterbukaan ekonomi mempunyai nilai rata-rata 1.2 serta standar deviasi 0.8. Kemudian, IPM mempunyai nilai paling rendah 0.5 , nilai paling tinggi 0.9 , dan secara menyeluruh variabel IPM memiliki nilai rata-rata 0.7 serta standar deviasi 0.1.

Selanjutnya penelitian ini menggunakan uji regresi data panel untuk menganalisis dan mengetahui pengaruh perdagangan internasional dan keterbukaan ekonomi terhadap Indeks Pembangunan Manusia (IPM) di negara-negara Asean. Adapun hasil pengujian menggunakan bantuan software eviews 9 sebagai berikut:

1. Uji Pemilihan Model

a) Hasil Uji Chow

Uji Chow Merupakan pengujian yang dilakukan untuk memilih apakah model yang digunakan Common Effect atau Fixed Effect. Hipotesis dari uji ini adalah: 


$$
\begin{aligned}
& \mathrm{H} 0=\text { Common Effect Model } \\
& \mathrm{Ha}=\text { Fixed Effect Model } .
\end{aligned}
$$

Redundant Fixed Effects Tests

Tabel 2. Hasil Uji Chow

Equation: Untitled

Test cross-section fixed effects

\begin{tabular}{llll}
\hline Effects Test & Statistic & d.f. & Prob. \\
\hline Cross-section F & 87.428009 & $(7,44)$ & 0.0000 \\
Cross-section Chi-square & 139.509083 & 7 & 0.0000 \\
\hline
\end{tabular}

Dari hasil regresi Tabel di atas, didapatkan nilai probabilitas untuk Cross-section F sebesar 0,0000 yang nilainya $<0,05$. Maka $\mathrm{H}_{0}$ di tolak dan $\mathrm{H}_{\mathrm{a}}$ di terima, artinya dapat disimpulkan bahwa model Fixed Effect lebih baik dibandingkan dengan model Common Effect.

b) Hasil Uji Hausman

Uji Hausman Merupakan pengujian statistik yang dilakukan untuk memilih apakah model yang digunakan Fixed Effect Model atau Random Effect Model. Dimana hipotesisnya adalah:

$$
\begin{aligned}
& \mathrm{H} 0=\text { Random Effect Model }(\mathrm{REM}) \\
& \mathrm{Ha}=\text { Fixed Effect Model }(\mathrm{FEM})
\end{aligned}
$$

Tabel 3. Hasil Uji Hausman

Correlated Random Effects - Hausman Test

Equation: Untitled

Test cross-section random effects

\begin{tabular}{lrrr}
\hline Test Summary & Chi-Sq. Statistic & Chi-Sq. d.f. & Prob. \\
\hline Cross-section random & 741667.693611 & 3 & 0.0000 \\
\hline
\end{tabular}

Berdasarkan hasil estimasi Uji Hausman dalam menentukan Fixed Effect Model atau Random effect Model, di peroleh nilai probabilitas $\mathrm{P}$ Value (Prob $>\mathrm{Chi}^{2}$ ) < Alpha 0,05 maka $\mathrm{H}_{0} \mathrm{di}$ tolak dan $\mathrm{H}_{\mathrm{a}}$ di terima. sehingga dapat disimpulkan bahwa penggunaan pilihan model yang terbaik adalah Fixed Effect.

Dari serangkaian uji pemilihan model di atas didapatkan hasil bahwa dari uji chow test terpilih model Fixed Effect daripada Common Effect, dan dari uji hausman test terpilih model fixed effect daripada random effect, sehingga model terbaik yang digunakan dalam penelitian ini adalah model fixed effect 
2. Pengujian Hipotesis

Tabel 4. Hasil Estimasi Fixed Effec Model

\begin{tabular}{crrrc}
\hline \multicolumn{1}{c}{ Variable } & Coefficient & Std. Error & t-Statistic & Prob. \\
\hline C & 4.314879 & 1.049561 & 4.111129 & 0.0002 \\
X1 & $7.99 \mathrm{E}-17$ & $3.94 \mathrm{E}-17$ & 2.030002 & 0.0484 \\
X2 & $0.10 \mathrm{E}-16$ & $2.88 \mathrm{E}-17$ & -3.813585 & 0.0084 \\
X3 & 0.910000 & $3.05 \mathrm{E}-17$ & $3.28 \mathrm{E}+16$ & 0.0098 \\
\multicolumn{5}{c}{ Effects Specification } \\
\\
Cross-section fixed (dummy & variables) & & \\
R-squared & 0.870000 & Mean dependent var & $1.68 \mathrm{E}+16$ \\
Adjusted R-squared & 0.590000 & S.D. dependent var & $1.86 \mathrm{E}+16$ \\
S.E. of regression & 0.703025 & Akaike info criterion & 4.079546 \\
Sum squared resid & 127.6130 & Schwarz criterion & 4.481013 \\
Log likelihood & -101.1875 & Hannan-Quinn criter. & 4.234796 \\
F-statistic & $6.41 \mathrm{E}+32$ & Durbin-Watson stat & 1.641545 \\
Prob(F-statistic) & 0.000000 & & \\
\hline
\end{tabular}

Berdasarkan hasil uji chou, dan uji hausman pada tabel diatas terpilih model yang terbaik yaitu model fixed effect sebagai model estimasi untuk mengetahui pengaruh variabel perdagangan internasional yang di proksikan dengan nilai ekspor dan impor, dan variabel keterbukaan ekonomi terhadap indeks pembangunan manusia (IPM). Dari hasil persamaan tersebut, maka dapat diinterpretasikan secara ekonomi sebagai berikut:

a). Koefisien Determinasi $\left(\mathrm{R}^{2}\right)$

Koefisien determinasi $\left(\mathrm{R}^{2}\right)$ memiliki fungsi untuk mengukur sejauh mana kemampuan variabel independen secara simultan dapat menjelaskan variabel dependen. Berdasarkan tabel diatas, di ketahui nilai koefisien determinasi $\left(\mathrm{R}^{2}\right)$ sebesar 0.87000 , artinya variabel independen (ekspor, impor dan keterbukaan ekonomi) mampu menejelaskan variabel dependen (IPM) sebesar $87 \%$. Sementara sisanya dijelaskan oleh variabel lain di luar model.

\section{b). Uji Simultan (Uji F)}

Estimasi yang digunakan dalam penelitian ini menggunakan regresi data panel dengan pendekatan terpilih adalah fixed effect model. Pada penelitian ini menggunakan nilai signifikansi a sebesar 5\% $(0,05)$. Hasil pengujian statistik secara simultan dapat diketahui bahwa nilai probabilitas F sebesar 0,000 lebih kecil dari tingkat signifikansi alpha 5\%. Sehingga keputusannya adalah hipotesis nol ditolak dan menerima hipotesis alternatif. Artinya, variabel ekspor, impor dan keterbukaan ekonomi secara signifikan bersama-sama mempengaruhi indeks pembangunan manusia (IPM) pada tingkat kepercayaan 95\% $(\alpha=0,05)$. Hal ini sejalan dengan teori yang menyatakan bahwa keterbukaan ekonomi melalui perdagangan internasional berpengaruh siginifikan terhadap indeks pembangunan manusia (UNDP, 2006).

c) Uji Signifikansi Parameter Individual (Uji T)

Uji t digunakan untuk menguji pengaruh variabel independen secara individual terhadap variabel dependen. Derajat kepercayaan yang digunakan untuk penelitian ini sebesar $95 \%(\alpha=$ $0,05)$. Apabila nilai signifikansi $<0,05$ maka Ha diterima. Hal ini menandakan bahwa variabel independen secara parsial/individu dapat berpengaruh terhadap variabel dependen. 


\section{Pembahasan}

a) Pengaruh Ekspor terhadap Indeks Pembangunan Manusia

Nilai probabilitas dari hasil penelitian ini adalah 0.0484. hasil ini menunjukkan bahwa variabel independen memiliki hubungan positif dan signifikan terhadap variabel dependen, Hasil penelitian ini sejalan dengan hipotesis yang menyatakan bahwa perdagangan internasional berpengaruh signifikan terhadap IPM. Hal ini disebabkan karena kebijakan yang terjadi di negara Asean mampu menghasilkan kualitas maupun kuantitas ekspor yang efektif dalam meningkatkan kualitas hidup masyarakat. Secara teori hubungan positif antara perdagangan dan pembangunan manusia, menyatakan bahwa aktivitas perdagangan akan melahirkan standar hidup yang lebih besar. Manfaat tersebut pada akhirnya melahirkan suatu kebijakan yang berorientasi pada kualitas pendidikan, perawatan kesehatan dan layanan sosial yang lebih baik (Davies \& Quinlivan, 2006).

Akmal, Ahmad, Ahmad \& Butt (2007) menjelaskan pengaruh positif secara langsung perdagangan internasional (ekspor) terhadap pembangunan manusia adalah melalui para eksportir, artinya tingkat ekspor yang tinggi dapat meningkatkan pendapatan pengusaha, tenaga kerja, dan dalam beberapa kondisi berpengaruh terhadap peningkatan jumlah tenaga kerja.

Hal ini di perkuat dengan penelitian Sabaruddin (2015) yaitu melakukan evaluasi dampak dari perdagangan internasional terhadap kesejahteraan masyarakat di Indonesia. Pada bagian ekspor, hasil penelitian menyimpulkan bahwa komoditi Pertanian, yang melakukan ekspor dapat berpengaruh terhadap kesejahteraan masyarakat melalui jalur tenaga kerja. Hasil penelitian ini sejalan dengan (Afzal et al., 2009) meneliti hubungan antara pembangunan manusia, ekspor, dan pertumbuhan ekonomi di Pakistan dengan menggunakan data seri waktu tahunan dari 1971 hingga 2009. Hasil dari autoregressive distributive lag (ARDL) menunjukkan bahwa ekspor memiliki pengaruh signifikan pada pembangunan manusia.

\section{b). Pengaruh Impor terhadap Indeks Pembangunan Manusia}

Nilai probabilitas dari hasil penelitian ini adalah 0.0084 . Hasil ini menunjukkan bahwa variabel impor berpengaruh positif dan signifikan terhadap indeks pembangunan manusia (IPM) di negara-negara Asean pada tahun 2013-2019. Pada dasarnya kebutuhan akan barang dan jasa dari suatu negara dapat terpenuhi melalui kegiatan impor, dalam rangka memenuhi kebutuhan masyarakat dan bahan baku produksi bagi perusahaan. Namun apabila terjadi impor yang terlalu tinggi maka dapat menyebabkan pengeluaran negara yang cukup besar. Secara teori aktivitas impor yang lebih besar dari ekspor akan menyebabkan defisit perdagangan yang pada akhirnya akan berdampak terhadap turun nya pertumbuhan ekonomi (Astuti \& Ayuningtyas, 2018). Sebaliknya kebijakan impor yang efektif dan efisien dapat menyebabkan terjadinya peningkatan pertumbuhan ekonomi. Pertumbuhan ekonomi akan berpengaruh terhadap indeks pembangunan manusia (IPM), karena pertumbuhan ekonomi merupakan bagian dari komponen indeks pembangunan manusia (UNDP, 2006).

Hasil ini relevan dengan penelitian Sabaruddin (2015) yang menjelaskan pengaruh perdagangan internasional (impor) terhadap kesejahteraan masyarakat dapat melalui jalur utama yaitu jalur produksi dan jalur penerimaan pajak. Faktor produksi yang terdapat dalam proses perdagangan internasional ini merupakan tenaga kerja dan pengusaha yang memiliki pendapatan menengah yang terjadi di pedesaan dan perkotaan, sedangkan jalur penerimaan pajak berfungsi untuk mendanai proyek pembangunan atau infrastruktur yang berorientasi pelayanan 
publik dan produktif yang mencakup didalam nya layanan kesehatan dan pendidikan (Saragih, 2018).

c). Pengaruh Keterbukaan Ekonomi terhadap Indeks Pembangunan Manusia

Nilai dengan probabilitas dari penelitian ini adalah 0.0098. Hasil ini menunjukkan bahwa variabel keterbukaan ekonomi memiliki pengaruh positif dan signifikan terhadap Indeks Pembangunan Manusia (IPM) di negara-negara Asean pada tahun 2013-2019. Secara teoritis penelitian ini sesuai dengan teori keterbukaan ekonomi yang memiliki dampak terhadap pendapatan domestik bruto yang menjadi bagian dari komposit dalam mengukur pembangunan manusia (UNDP, 2006) sekaligus menjadi stimulator yang efektif dalam menunjang pembangunan suatu negara melalui adanya transaksi perdagangan internasional (Kabadayi, 2013). IPM juga dijadikan sebagai alat ukur dalam menilai dampak dari kebijakan ekonomi terhadap kualitas hidup masyarakat di suatu negara (Davies \& Quinlivan, 2006). Keterbukaan ekonomi suatu negara akan memberikan gambaran mengenai keuntungan yang diperoleh. Dari keuntungan-keuntungan tersebut mampu menggerakkan peningkatan kualitas sumberdaya manusia dalam negeri, hal ini terjadi karena keterbukaan ekonomi menjadi daya tarik bagi investor asing untuk masuk, sehingga semakin besar investasi yang masuk disuatu negara maka semakin besar pula benefit yang dapat diperoleh oleh negara host (Golub, 2009).

Sejalan dengan ini, Jadoon, Rashid \& Azeem (2015) melakukan penelitian yang berjudul liberalisasi perdagangan, modal manusia dan pertumbuhan ekonomi di negara-negara Asia. Penelitian ini menemukan hasil bahwa, dampak keterbukaan perdagangan terhadap modal manusia berpengaruh signifikan. Hal ini disebabkan persaingan yang ketat antar negara akan menciptakan sumber daya manusia yang terlatih. Output dari keterbukaan perdagangan dalam bentuk peningkatan produktivitas bagi sumber daya manusia.

Hasil ini juga diperkuat dengan penelitian yang dilakukan oleh Nourzad \& Powell (2003) menyelidiki hubungan antara keterbukaan ekonomi dengan pertumbuhan ekonomi dan pembangunan manusia dengan menggunakan data rata-rata 47 negara berkembang dari 1965 hingga 1990. Hasil penelitian menemukan bahwa keterbukaan ekonomi dapat mempengaruhi pertumbuhan ekonomi serta pembangunan manusia.

\section{SIMPULAN DAN REKOMENDASI}

Penelitian ini memiliki tujuan untuk memberikan informasi mengenai pengaruh perdagangan internasional dan keterbukaan ekonomi terhadap indeks pembangunan manusia (IPM) di Asean selama periode 2013-2019, menggunakan variabel indeks pembangunan manusia (IPM) sebagai variabel dependen sedangkan perdagangan internasional yang di proksikan dengan nilai ekspor dan impor dan keterbukaan ekonomi sebagai variabel independen. Hasil penelitian menunjukkan bahwa secara simultan maupun parsial variabel ekspor, impor, dan keterbukan ekonomi berpengaruh signifikan terhadap indeks pembangunan manusia di Asean. Temuan penelitian ini memberikan gambaran mengenai penting nya suatu negara dalam melihat kebijakan mengenai pembangunan yang dilakukan, terutama mengenai pembangunan manusia. Karena setiap pembangunan yang dilakukan idealnya harus berorientasi dari dan untuk manusia itu sendiri. Kebijakan pembangunan nasional hanya menjadi alat dalam mencapai tujuan tersebut. Termasuk di dalamnya kebijakan mengenai perdagangan internasional (ekspor dan impor), serta keterbukaan ekonomi yang merupakan bagian fundamental dalam pembangunan suatu negara. Kebijakan 
tersebut tidak hanya berdampak terhadap pertumbuhan ekonomi saja, tetapi akan menimbulkan multiplier effect (efek pengganda) bagi sektor-sektor yang memiliki korelasi secara langsung terhadap kualitas pembangunan manusia, terutama melalui sektor tenaga kerja dan penerimaan pajak (Fiskal).

Adapun keterbatasan dalam penelitian ini adalah hanya menggunakan ekspor, impor dan keterbukaan ekonomi dalam menilai determinasi indeks pembangunan manusia. Isu mengenai pembangunan manusia merupakan isu yang kompleks yang melibatkan banyak aspek dan variabel dalam mempengaruhinya. Peneliti berharap penelitian berikutnya dapat menambahkan variabel makro dan mikro secara bersamaan, agar determinasi dari pembangunan manusia dapat dilihat dalam kerangka perspektif yang lebih komprehensif. Selanjutnya, penulis merekomendasikan agar penelitian berikutnya memakai metode panel dinamis, karena penelitian ini menggunakan objek yaitu berupa negara (crossection) yang lebih banyak di bandingkan dengan waktu penelitian (time series), sehingga hasil penelitian dapat di komparasikan dalam melihat pemilihan metode yang terbaik.

\section{DAFTAR PUSTAKA}

Acaravci, A., \& Akalin, G. (2017). Environment-Economic Growth Nexus : A Comparative Analysis of Developed and Developing Countries. International Journal of Energy Economics and Policy, 7(5), 34-43.

Afzal, M., Butt, A. R., Rehman, H. U., \& Begum, I. (2009). A Dynamic Analysis of the Relationship among Human Development, Exports and Economic Growth in Pakistan. The Pakistan Development Review, 48(4), 885-920. https://doi.org/10.30541/v48i4IIpp.885-920

Akmal, M. S., Ahmad, Q. M., Ahmad, M. H., \& Butt, M. S. (2007). An Empirical Investigation of the Relationship between Trade Liberalization and Poverty Reduction: A Case for Pakistan. The Lahore Journal of Economics, 12(1), 99-118.

Arisman. (2018). Determinant of Human Development Index in ASEAN Countries. Signifikan: Jurnal Ilmu Ekonomi, $\quad 7(1), \quad 113-122$. https://doi.org/htttp://dx.doi.org/10.15408/sjie.v7i1.6756

Ashraf, Q. H., Weil, D. N., \& Wilde, J. (2011). The Effect of Interventions to Reduce Fertility on Economic Growth (No. 2011-14).

Astuti, I. P., \& Ayuningtyas, F. J. (2018). Pengaruh Ekspor dan Impor Terhadap Pertumbuhan Ekonomi di Indonesia. Jurnal Ekonomi \& Studi Pembangunan, 19(1), 1-10. https://doi.org/10.18196/jesp.19.1.3836

Aydin, C. (2021). Kenkoku University and the Experience of Pan-Asianism: Education in the Japanese Empire by Yuka Hiruma Kishida. The Journal of Japanese Studies, 47(1), 228232. https://doi.org/10.1353/jjs.2021.0034

Bagolin, I. (2014). Human Development Index (HDI) - A Poor Representation to Human Development Approach. July.

Barrington-Leigh, C., \& Escande, A. (2017). Measuring Progress and Well-Being: A Comparative Review of Indicators. Social Indicators Research, 135(3), 1-51. https://doi.org/10.1007/s11205-016-1505-0

Bollen, K. A., \& Brand, J. E. (2010). A General Panel Model with Random and Fixed Effects: A Structural Equations Approach. Social Forces, 89(1), 1-34. https://doi.org/10.1353/sof.2010.0072 
Calderón, C. (2004). Trade Openness and Real Exchange Rate Volatility: Panel Data Evidence (No. 294).

Davies, A., \& Quinlivan, G. (2006). A Panel Data Analysis of the Impact of Trade on Human Development. The Journal of Socio-Economics, 35(5), 868-876. https://doi.org/https://doi.org/10.1016/j.socec.2005.11.048

Diputra, T. B. (2017). Pengaruh Keterbukaan Ekonomi Terhadap Indeks Pembangunan Manusia di Indonesia Tahun 2000-2015. Universitas Hasanuddin.

Dollar, D., \& Kraay, A. (2004). Trade, Growth, and Poverty. The Economic Journal, 114(493), F22-F49. https://www.jstor.org/stable/3590109

Eusufzai, Z. (1996). Openness, Economic Growth, and Development: Some Further Results. Economic Development and Cultural Change, 44(2), 333-338. https://www.jstor.org/stable/1154406

Golub, S. S. (2009). Openness to Foreign Direct Investment in Services: An International Comparative Analysis. World Economy, 32(8), 1245-1268. https://doi.org/10.1111/j.1467-9701.2009.01201.x

Gujarati, D. N., C.Porter, D., \& Mangunsong, R. C. (2012). Dasar-Dasar Ekonometrika Buku 2 Edisi 5 (Basic Econometrics) (5th ed.). Salemba Empat.

Halid, A., \& Yapanto, L. M. (2021). The Determination Priority? Local Government Policy Increasing the Human Development Index in Indonesia (Case Study: Gorontalo Province). Journal of Xi'an Shiyou University, Natural Science Edition, 17(04), 65-79. http://xisdxjxsu.asia

Hamid, Z., \& Amin, R. M. (2013). Trade and Human Development in OIC Countries: A Panel Data Analysis. 8th International Conference on Islamic Economics and Finance, 21(2), $55-70$.

Herawati, A., \& Fauzia, F. I. (2018). The Effect of Current Ratio, Debt to Equity Ratio and Return on Asset on Dividend Payout Ratio in Sub-sector Automotive and Component Listed in Indonesia Stock Exchange in Period 2012 - 2016. The 2018 International Conference of Organizational Innovation, 2018(KnE Social Sciences), 1076-1086. https://doi.org/10.18502/kss.v3i10.3450

Hsiao, C. (2003). Analysis of Panel Data. In Cambridge University Press (2nd editio). https://doi.org/https://doi.org/10.1017/CBO9780511754203

Hye, Q. M. A. (2012). Exports, Imports and Economic Growth in China: an ARDL Analysis. Journal of Chinese Economic and Foreign Trade Studies, 5(1), 42-55. https://doi.org/10.1108/17544401211197959

Hye, Q. M. A., \& Lau, W.-Y. (2015). Trade Openness and Economic Growth: Empirical Evidence from India. Journal of Business Economics and Management, 16(1), 188-205. https://doi.org/https://doi.org/10.3846/16111699.2012.720587

Jadoon, A. K., Rashid, H. A., \& Azeem, A. (2015). Trade Liberalization , Human Capital and Economic Growth: Empirical Evidence from Selected Asian Countries. Pakistan Economic and Social Review, 53(1), 113-132. https://www.jstor.org/stable/26153251

Jawaid, S. T., \& Waheed, A. (2017). Contribution of International Trade in Human Development of Pakistan. Global Business Review, 18(5), 1155-1177. https://doi.org/10.1177/0972150917710345 
Kabadayi, B. (2013). Human Development and Trade Openness: A Case Study on Developing Countries. Advances in Management \& Applied Economics, 3(3), 193-199. https://ideas.repec.org/a/spt/admaec/v3y2013i3f3_3_12.html

Kong, Q., Peng, D., Ni, Y., Jiang, X., \& Wang, Z. (2021). Trade Openness and Economic Growth Quality of China: Empirical Analysis using ARDL Model. Finance Research Letters, 38. https://doi.org/https://doi.org/10.1016/j.frl.2020.101488

Lamba, A., Novan, R., Lamba, R. A., \& Patma, K. (2020). The Impact of Economic Growth and Capital Expenditures in Supporting Quality Human Development. The International Journal of Social Sciences World, 2(02), 100-109. https://doi.org/https://doi.org/10.5281/zenodo.4067803

Leach, L. F., Henson, R. K., Finch, W. H., Newman, I., \& Walker, D. A. (2007). Multiple Linear Regression Viewpoints. 33(1).

Lumbantoruan, E. P., \& Hidayat, P. (2013). Analisis Pertumbuhan Ekonomi dan Indeks Pembangunan Manusia (IPM) Provinsi-Provinsi di Indonesia (Metode Kointegrasi). Jurnal Ekonomi Dan Keuangan, 2(2), 14-27.

Mankiw, N. G. (2006). The Macroeconomist as Scientist and Engineer. 20(4), 29-46.

Nourzad, F., \& Powell, J. J. (2003). Openness , Growth , and Development : Evidence from a Panel of Developing Countries. Scientific Journal of Administrative Development, 1(1), 72-94.

Nowbutsing, B. M. (2014). The Impact of Openness on Economic Growth: Case of Indian Ocean Rim Countries. Journal of Economics and Development Studies, 2(2), 407-427.

Pernia, E. M., \& Quising, P. F. (2005). Trade Openness and Regional Development in a Developing Country. In Globalization and Urban Development (pp. 79-94). Springer. https://doi.org/10.1007/3-540-28351-X_6

Razmi, S. M. J., \& Yavari, Z. (2012). Reviewing the Effect of Trade Openness on Human Development. Interdisciplinary Journal of Contemporary Research in Business, 4(6), 970-978.

Sabaruddin, S. S. (2015). Dampak Perdagangan Internasional Indonesia terhadap Kesejahteraan Masyarakat: Aplikasi Structural Path Analysis. Buletin Ekonomi Moneter Dan Perbankan, 17(4), 433-456. https://doi.org/https://doi.org/10.21098/bemp.v17i4.505

Saragih, A. H. (2018). An Analysis of Local Taxes Revenue's Effect on Human Development Index. https://doi.org/10.21831/economia.v14i2.21595

Secretariat, ASEAN. (2016). Strengthening the Information Resource Management Division (IRMD) (Formerly: ASEAN Secretariat (ASEC) Resource Centre (ARC)) - Improvement and Development of Database.

Sharma, B., \& Gani, A. (2004). Human Development The Effects of Foreign Direct Investment on Human Development. 4(2).

Sholiha, E. U. N. (2015). Structural Equation Modeling-Partial Least Square Untuk Pemodelan Derajat Kesehatan Kabupaten/Kota Di Jawa Timur (Studi Kasus Data Indeks Pembangunan Kesehatan Masyarakat Jawa Timur 2013). Institut Technology Sepuluh Nopember.

Suri, T., Boozer, M. A., Ranis, G., \& Stewart, F. (2011). Paths to Success: The Relationship Between Human Development and Economic Growth. World Development, 39(4), 506522. https://doi.org/https://doi.org/10.1016/j.worlddev.2010.08.020 
Tanaka, Y. (2020). Involuntary Unemployment and Fiscal Policy for Full-Employment. Theoretical Economics Letters, 10(4), 745-757. https://doi.org/10.4236/tel.2020.104046

UNDP, U. N. D. P. (2006). Asia-Pacific Human Development Report 2006: Trade on Human Terms.

Wibowo, M. G. (2016). Kebijakan Pembangunan Nasional: dari Pertumbuhan (Growth) Menuju Kebahagiaan (Happiness). Asy-Syir'ah Jurnal Ilmu Syari'ah Dan Hukum, 50(1), 223-239. https://doi.org/http://dx.doi.org/10.14421/asy-syir'ah.2016.501-10

Widarjono, A. (2017). Ekonometrika Pengantar dan Aplikasinya. UPP STIM YKPN. 